\title{
Effect of frother on bubble-particle collision probability of fine particles
}

\author{
Behzad Shahbazi
}

Mining Engineering Department, Science and Research Branch, Islamic Azad University, Tehran, Iran

Email address:

bzshahbazi@yahoo.com

To cite this article:

Behzad Shahbazi. Effect of Frother on Bubble-Particle Collision Probability of Fine Particles. American Journal of Chemical Engineering. Special Issue: Flotation Technology. Vol. 3, No. 2-2, 2015, pp. 1-5. doi: 10.11648/j.ajche.s.2015030202.11

\begin{abstract}
The frothers are influence on the ability of bubbles to collect particles from the pulp and carry them to the froth layer. In this study the effect of type and dosage of frothers on bubble-particle collision probability and dispersion of fine particles was investigated. Therefore, collision probability of fine particles was calculated using frothers such as MIBC, Pine Oil, and Poly propylene glycol with concentration of $0,25,50$ and $75 \mathrm{~g} / \mathrm{t}$ respectively. According to this study, as the particle size increased the probability of collision increased but with using Poly Propylene Glycol, MIBC and Pine Oil, probability of collision increased, respectively. Under Potential flow conditions, Maximum collision probability was obtained $27.27 \%$ with Poly Propylene Glycol dosage of $75 \mathrm{~g} / \mathrm{t}$ and particle size of $50 \mu \mathrm{m}$.
\end{abstract}

Keywords: Flotation, Frother, Fine particles, Dispersion, Collision

\section{Introduction}

The importance of frothers in flotation is widely acknowledged, particularly in terms of their role with respect to bubble size and the stability and mobility of the froth phase. This factor plays a significant role in the kinetic viability of the process and the overall recovery and grade that can be achieved from a flotation cell [1].

Overall, the primary action of frothers in flotation is deceptively simple. Frothers are surface-active molecules, which preferentially adsorb at a gas-liquid interface, reducing the interfacial surface tension. In the liquid, or pulp phase of a flotation cell, the presence of frother molecules at the interface stabilizes the liquid film surrounding a bubble, inhibiting bubble coalescence and aiding particle bubble attachment. In the froth phase, the adsorbed molecules stabilize the froth by inhibiting drainage of liquid from the bubble lamellae [2-4].

For flotation occurring under quiescent conditions, one can calculate the probability of collision using stream functions. The stream functions used by earlier workers are applicable for bubbles that are either too large or too small $[5,6]$, while those developed in recent years are useful for flotation size bubbles [7, 8]. However, most of the flotation machines are operated under intensely agitated conditions, which make it difficult to use the interceptional collision models based on stream functions. Under such conditions, models based on microturbulence may be more useful [9].

So far, the effect of hydrodynamic parameters on the flotation response of coarse and fine particles has been widely investigated [10-16]. This study focuses on the effect of type and dosage of frother on the fine particles collision probability in laboratory flotation cell. These two parameters are influence on bubble size distribution and bubble size is an important parameter, which has a strong influence on the flotation rate constant and flotability of fine particles. So, influence of some frothers such as MIBC, Pine Oil and Poly propylene glycol on collision probability of fine particles has been investigated.

Also, for fine particles, bubble- particle collision Probability was calculated using different equations. Under Potential flow conditions, maximum collision probability was obtained $27.27 \%$ with Poly Propylene Glycol dosage of $75 \mathrm{~g} / \mathrm{t}$ and particle size of $50 \mu \mathrm{m}$. So, this results show that difficulty in floating fine particles is due to collision probability of fine particles is very low.

\section{Materials and Methods}

Bubble size distribution was measured for a mechanical Flotation cell. MIBC (Methyl Isobutyl carbonyl), Pine Oil and Poly propylene glycol $\left(\mathrm{A}_{65}\right)$ with concentration of 0,25 , 
50 and $75 \mathrm{~g} / \mathrm{t}$ were used as frother. An impeller diameter of 0.07 meter was used for agitation with impeller speed of $1100 \mathrm{rpm}$ and a cell with square section was used that its length and height were 0.12 and 0.1 meters, respectively. The type of impeller was Rushton turbine with 8 paddles and a stator was used around the rotor.

Bubble size distribution was measured similar to McGill bubble viewer. It consists of a sampling tube attached to a viewing chamber with a window inclined from vertical. The closed assembly is filled with water of similar nature to that in the flotation cell (to limit changes in bubble environment during sampling) and the tube is immersed to the desired location below the froth. Bubble raise into the viewing chamber and are imaged by a digital photo camera as they slide up the inclined window illuminated from behind [17].

\section{Results and Discussions}

\subsection{Bubble Size Distribution}

In this research, bubble size distribution was measured similar to McGill bubble viewer [17]. The mean bubble diameter adopted was the Sauter diameter, calculated by the equation below [18]:

$$
d_{32}=\sum n_{i} d_{i}^{3} / \sum n_{i} d_{i}^{2}
$$

in which $\mathrm{n}$, is number of bubbles and $\mathrm{d}$ is bubble diameter. The effect of type and dosage of frothers on bubble size distribution and Sauter mean bubble diameter has been shown in Fig. 1 and Table 1, respectively. In this research, with increasing frother dosage, bubble diameter, $\mathrm{d}_{32}$, decreased and when Poly Propylene Glycol $\left(\mathrm{A}_{65}\right)$, MIBC and Pine Oil were used as frother, bubble diameter increased, respectively. Maximum bubble diameter was obtained around Pine Oil and frother dosage of $25 \mathrm{~g} / \mathrm{t}$ and minimum bubble diameter was obtained around Poly Propylene Glycol and frother dosage of $75 \mathrm{~g} / \mathrm{t}$.

Table 1. Bubble diameter at various type and dosage of frothers

\begin{tabular}{llll}
\hline Frother & Dosage $\mathbf{g} / \mathbf{t}$ & $\mathbf{d}_{\mathbf{3 2}}(\mathbf{m m})$ & $\mathbf{d}_{\mathbf{m a x}}(\mathbf{m m})$ \\
\hline \multirow{3}{*}{ MIBC } & 0 & 1 & 1.65 \\
& 25 & 0.84 & 1.45 \\
& 50 & 0.61 & 1.05 \\
& 75 & 0.64 & 0.90 \\
Pine Oil & 0 & 1 & 1.65 \\
& 25 & 1.75 & 2.15 \\
& 50 & 1.27 & 1.75 \\
& 75 & 1.31 & 1.85 \\
& 0 & 1 & 1.65 \\
$\mathrm{~A}_{65}$ & 25 & 0.61 & 1.15 \\
& 50 & 0.59 & 1.05 \\
& 75 & 0.55 & 1.05 \\
\hline
\end{tabular}
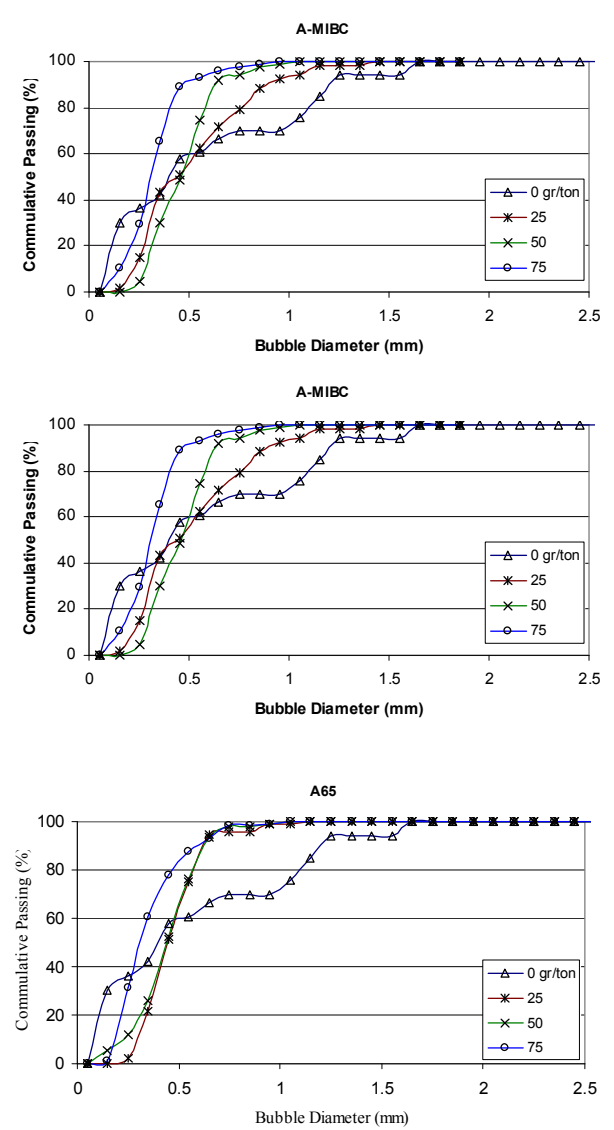

Figure 1. Bubble size distribution at various type and dosage of frothers

Furthermore, MIBC, Pine Oil and Poly Propylene Glycol were mixed together in equal proportion like MIBC and Pine Oil (MPO), MIBC and Poly Propylene Glycol (MPP), Pine Oil and Poly Propylene Glycol (POPG) and MIBC and Poly Propylene Glycol and Pine Oil (MPOPG). According to Table 2 and Fig. 2, when MPO (25 g/t) was used, bubble diameter was more than other mixed frothers. With increasing frother dosage to $150 \mathrm{~g} / \mathrm{t}$, the bubble diameter decreased.

Table 2. Bubble diameter at various type and dosage of mixed frothers

\begin{tabular}{|c|c|c|c|}
\hline Frother & Dosage $g / t$ & $\mathrm{~d}_{32}(\mathrm{~mm})$ & $d_{\max }(\mathrm{mm})$ \\
\hline \multirow{2}{*}{ MIBC+ Pine Oil (MPO) } & 25 & 0.89 & 1.35 \\
\hline & 150 & 0.59 & 1.05 \\
\hline \multirow{2}{*}{$\mathrm{MIBC}+\mathrm{A}_{65}(\mathrm{MPP})$} & 25 & 0.70 & 1.45 \\
\hline & 150 & 0.56 & 0.95 \\
\hline \multirow{2}{*}{ Pine Oil $+\mathrm{A}_{65}(\mathrm{POPG})$} & 25 & 0.63 & 1.35 \\
\hline & 150 & 0.57 & 1.35 \\
\hline \multirow{2}{*}{$\begin{array}{l}\mathrm{MIBC}+\mathrm{A}_{65}+\text { Pine Oil } \\
(\mathrm{MPOPG})\end{array}$} & 25 & 0.75 & 1.25 \\
\hline & 150 & 0.52 & 0.85 \\
\hline
\end{tabular}



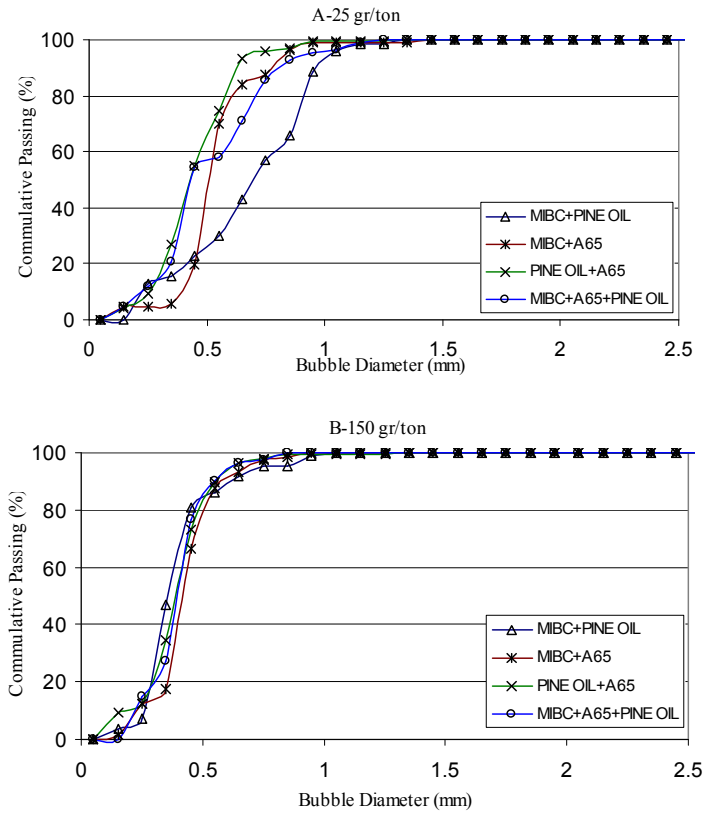

Figure 2. Bubble size distribution at various type and dosage of mixed frothers

\subsection{Collision Probability}

The probability $(\mathrm{P})$ of a particle being collected by an air bubble in the pulp phase of a flotation cell can be given by [19]:

$$
\begin{gathered}
P=P_{c} P_{a}\left(1-P_{d}\right) \\
P_{c}=A\left(d_{p} / d_{b}\right)^{n}
\end{gathered}
$$

Under Stokes flow conditions [5]:

$$
P_{c}=0.67\left(d_{p} / d_{b}\right)^{2}
$$

Under Potential flow conditions [6]:

$$
P_{c}=3\left(d_{p} / d_{b}\right)
$$

in which $\mathrm{P}_{c}$ is the probability of bubble particle collision, $\mathrm{P}_{\mathrm{a}}$ is the probability of adhesion, $P_{d}$ is the probability of detachment, $d_{p}$ is the diameter of particle and $d_{b}$ is the diameter of bubble.

Probability of collision was calculated for different conditions using Stokes and Potential equations. When collision probability was calculated using Stokes equation, amount of collision probability was very low but Potential equation could estimate probability of collision.

\subsubsection{Stokes Flow Conditions}

When collision probability was calculated using Stokes equation, amount of collision probability was very low. According to Fig. 3I, as the particle size increased the probability of collision increased and using Poly Propylene Glycol, MIBC and Pine Oil, probability of collision increased, respectively.
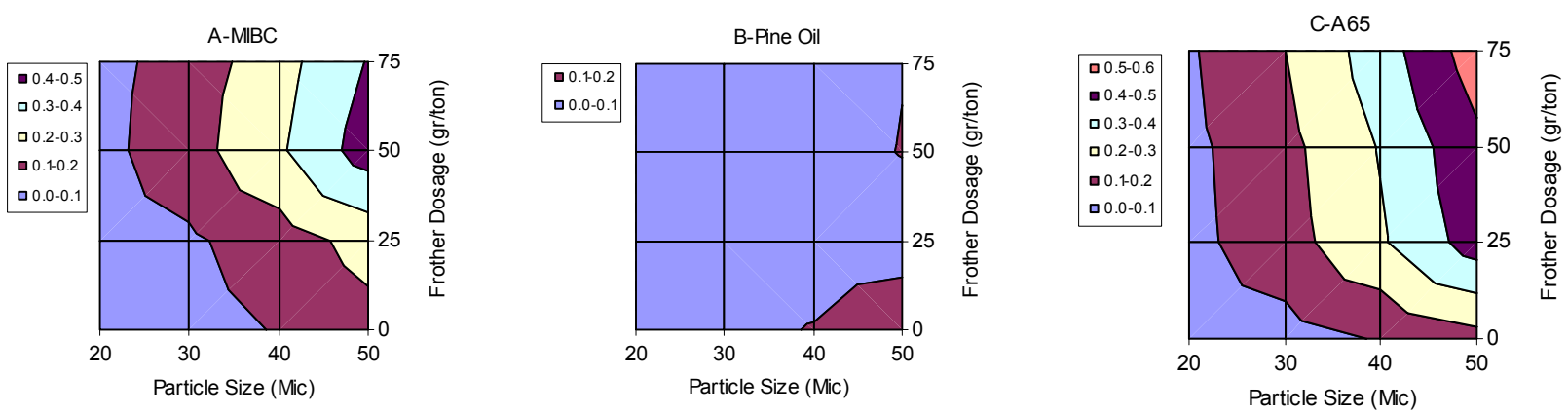

I) Stokes flow conditions
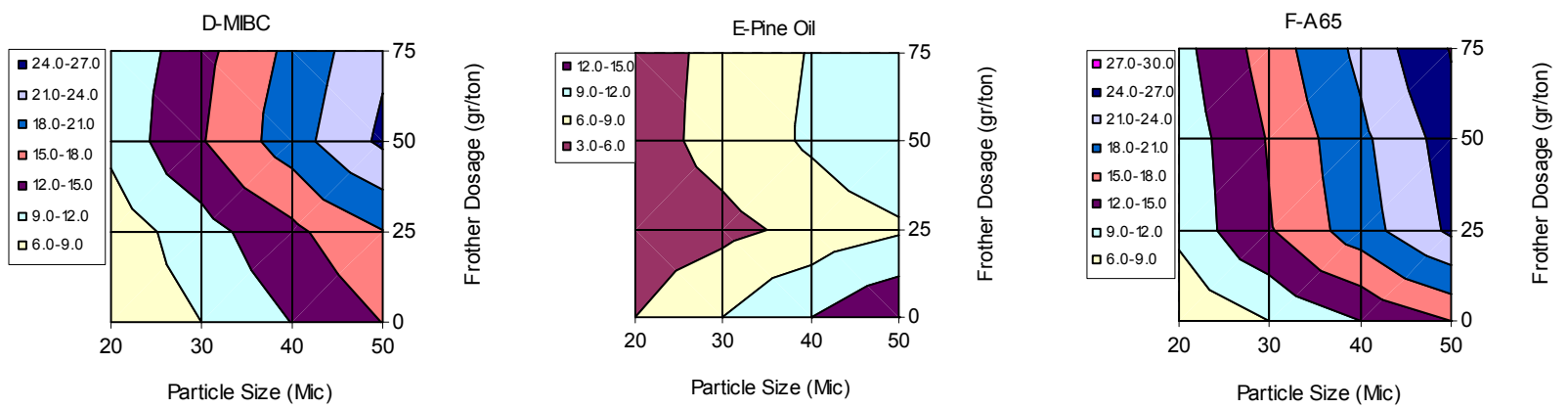

II) Potential flow conditions

Figure 3. Collision probability at various type and dosage of frothers and particle sizes 

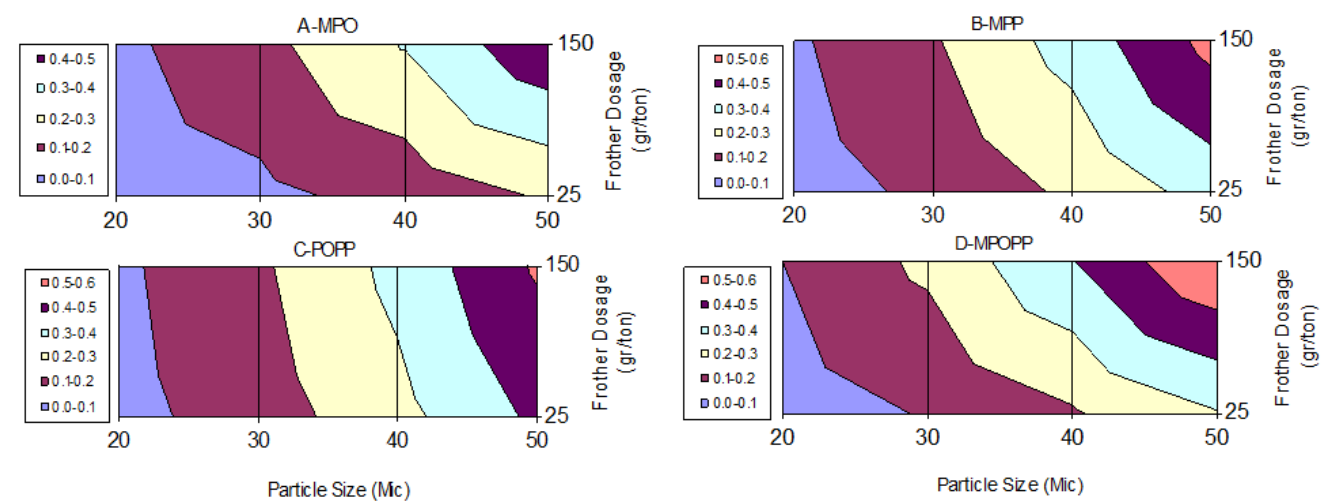

I) Stokes flow condition
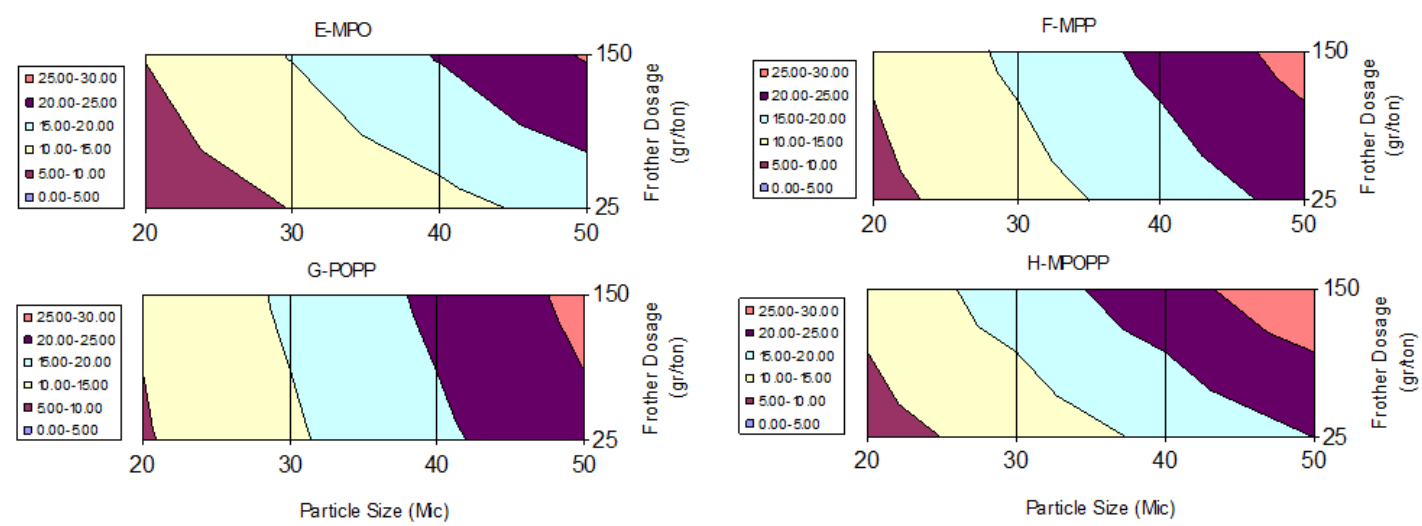

II) Potential flow condition

Figure 4. Collision probability at various type and dosage of mixed frothers and particle sizes

Maximum collision probability was obtained around $0.55 \%$ with Poly Propylene Glycol dosage of $75 \mathrm{~g} / \mathrm{t}$ and particle size of $50 \mu \mathrm{m}$.

According to Fig. 4I, when frother dosage was $25 \mathrm{~g} / \mathrm{t}$, using MPO, MPOPP, MPP and POPP as frothers, collision probability increased, respectively and when frother dosage was $150 \mathrm{~g} / \mathrm{t}$, using MPO, POPP, MPP and MPOPP as frothers, collision probability increased, respectively. With mixed frothers, maximum collision probability was obtained around $0.62 \%$ with MPOPP dosage of $150 \mathrm{~g} / \mathrm{t}$ and particles size of $50 \mu \mathrm{m}$.

\subsubsection{Potential Flow Conditions}

Potential equation estimated amount of collision probability more than Stokes equation. According to Fig. 3II, with increasing particle size, the collision probability increased and using Poly Propylene Glycol, MIBC and Pine Oil, collision probability increased, respectively. Maximum collision probability was obtained $27.27 \%$ with Poly Propylene Glycol dosage of $75 \mathrm{~g} / \mathrm{t}$ and particle size of $50 \mu \mathrm{m}$.

According to Fig. 4II, when frother dosage was $25 \mathrm{~g} / \mathrm{t}$, using MPO, MPOPP, MPP and POPP as frothers, collision probability increased, respectively and when frother dosage was $150 \mathrm{~g} / \mathrm{t}$, using MPO, POPP, MPP and MPOPP as frothers, collision probability increased, respectively. With mixed frothers, maximum collision probability was obtained around
$28.85 \%$ with MPOPP, frother dosage of $150 \mathrm{~g} / \mathrm{t}$ and particles size of $50 \mu \mathrm{m}$. So, increasing collision probability is possible with decreasing bubble diameter using MPOPP $(150 \mathrm{~g} / \mathrm{t})$.

\section{Conclosion}

With increasing frother dosage, bubble diameter, $\mathrm{d}_{32}$, decreased and when Poly Propylene Glycol $\left(\mathrm{A}_{65}\right)$, MIBC and Pine Oil were used as frother, bubble diameter increased, respectively.

Maximum bubble diameter was obtained around Pine Oil and frother dosage of $25 \mathrm{~g} / \mathrm{t}$ and minimum bubble diameter was obtained around Poly Propylene Glycol and frother dosage of $75 \mathrm{~g} / \mathrm{t}$.

When MPO (25 g/t) was used, bubble diameter was more than other mixed type frothers. With increasing frother dosage to $150 \mathrm{~g} / \mathrm{t}$, the bubble diameter decreased.

When collision probability was calculated using Stokes equation, amount of collision probability was very low. Maximum collision probability was obtained around $0.55 \%$ with Poly Propylene Glycol dosage of $75 \mathrm{~g} / \mathrm{t}$ and particle size of $50 \mu \mathrm{m}$ that is very low.

Under Stokes flow conditions, when frother dosage was 25 $\mathrm{g} / \mathrm{t}$, using MPO, MPOPP, MPP and POPP as frothers, collision probability increased, respectively and when frother 
dosage was $150 \mathrm{~g} / \mathrm{t}$, using MPO, POPP, MPP and MPOPP as frothers, collision probability increased, respectively.

Potential equation estimated amount of collision probability more than Stokes equation. According to Fig. 3II, with increasing particle size, the collision probability increased and using Poly Propylene Glycol, MIBC and Pine Oil, collision probability increased, respectively. Maximum collision probability was obtained $27.27 \%$ with Poly Propylene Glycol dosage of $75 \mathrm{~g} / \mathrm{t}$ and particle size of $50 \mu \mathrm{m}$.

Under Potential flow conditions, when frother dosage was $25 \mathrm{~g} / \mathrm{t}$, using MPO, MPOPP, MPP and POPP as frothers, collision probability increased, respectively and when frother dosage was $150 \mathrm{~g} / \mathrm{t}$, using MPO, POPP, MPP and MPOPP as frothers, collision probability increased, respectively. With mixed frothers, maximum collision probability was obtained around $28.85 \%$ with MPOPP, frother dosage of $150 \mathrm{~g} / \mathrm{t}$ and particles size of $50 \mu \mathrm{m}$.

\section{References}

[1] Comely, B. A., Harris, P. J., Bradshow, D. J. and Harris, M.C. (2002) Int J Miner Process, 64: 81-100.

[2] Klimpel, R. and Isherwood, S. (1991) Int J Miner Process, 33: 369-381.

[3] Laskowski, J.S. and Woodburn, E.T. (1998) Frothing in Flotation II, Gordon \& Breach, Australia, 2: 1-50.

[4] Zieminski, S., Caron, M. and Blackmore, R. (1967) I\&EC Fundam, 62: 233-242.

[5] Gaudin A.M. (1957) Flotation (2nd edition). McGraw-Hill, New York.
[6] Sutherland, K.L. (1948) J. Phys. Chem, 52: 394-425.

[7] Weber, M.E. and Paddock, D. (1983) J Colloid interfaceSci, 94: 328-335.

[8] Yoon, R.H and Luttrell, G.H. (1989) Int J Miner Process, 5: $101-122$.

[9] Schubert, H. and Bischofberger, C. (1979) 13th Int Miner Process Cong, Warszawa, 2: 1261-1287.

[10] Chehreh Chelgani, S., Shahbazi, B. and Rezai, B. (2010) Int J of Minerals, Metallurgy and Materials, 17: 526-534.

[11] Shahbazi, B., Rezai, B. and Koleini, S.M. Javad. (2008) Asian Journal of Chemistry, 3: 2180-2188.

[12] Shahbazi, B., Rezai, B. and Koleini, S.M. Javad. (2009) Minerals Engineering, 22: 57-63.

[13] Shahbazi, B., Rezai, B. and Koleini, S.M. Javad. (2010) Chemical Engineering and Processing, 49: 622-627.

[14] Shahbazi, B., Rezai, B. and Koleini, S.M. Javad, Noaparast M. (2013) Iran. J. Chem. Chem. Eng., 32: 109-118.

[15] Shahbazi, B., Rezai, B. and Koleini, S.M. Javad, Noaparast M. (2014) Geosciences ScientificQuarterlyJournal, in press.

[16] Shahbazi, B., Rezai, B. (2014) Journal of Dispersion Science and Technology, in press.

[17] Girgin, E.H., Do, S., Gomez, C.O. and Finch, J.A. (2006) Miner Eng, 19: 201-203.

[18] Rodrigues, R.T. and Rubio. (2003) Miner Eng, 16: 757-765.

[19] Yoon,R.H. (2000) Int J Miner Process, 58: 129-143. 